\title{
THE POLITICS OF SHAKESPEARE TRANSLATION AND PUBLICATION IN MALAYA
}

\author{
Nurul Farhana Low Bt Abdullah
}

\begin{abstract}
Introduction
The Sultan Idris Training College (SITC) was established in 1922 to train local Malay teachers to teach in the Malay vernacular schools. Entry to the college was based on competitive examinations among sons of peasant farmers and fishermen from village Malay vernacular schools. Roff (1967) contrasts students at this college with their counterparts from the Malay College in Kuala Kangsar (MCKK), who were mainly from the aristocratic class:
\end{abstract}

[A]t Kuala Kangsar, there were the sons of the traditional ruling class and the wealthy, undergoing training for entry into the English-speaking world of government and administration ... [whereas] at SITC, the sons of the peasantry and the poor [were] undergoing training for return to the Malay speaking world of the rural village school (p. 143).

Farish A. Noor (2002, p. 77) is more critical, describing the function of the SITC as being "primarily directed towards the goal of reproducing the Western stereotypes of the pleasant, nimble Malay agriculturist or the rustic Malay schoolteacher who was meant to return to the villages to teach skills that were more in keeping with their 'traditional rural' lifestyle." The teaching staff consisted of "one Filipino, four European, and nine Malay instructors [who] had been recruited to teach the students teaching methods as well as more 'traditional' skills like basket-weaving and gardening which were so beloved of the Colonial imagination" (ibid.). He observes that the two institutions "corresponded to the divisive nature of the Colonial Government's strategy of division and containment of the Malays into clearly-demarcated and policed spaces, namely, the urban space of the Malay Colonial-bureaucrats and the world of the tradition-bound rural peasantry"(p.78). Thus, “[t]he Colonial administrators were most concerned to ensure that the fragile socio-political hierarchy they had created under Colonial rule ... was maintained indefinitely via the divisive educational system they had introduced" (ibid.). 
The SITC was nevertheless a very important institution for Malay education as it was the only form of secondary education available in the Malay language. Headmaster O.T Dussek (quoted in Roff 1967, p.143) took pride in the fact that "every activity that is genuinely cultural and genuinely Malay has flourished in an astonishing manner" at the SITC. Malay students from all over the Peninsula lived and studied together at the college. Dussek explained that he and his staff wished to emphasize to the boys that they were all "essentially Malays, engaged in the joint task of raising the standard of Malay vernacular education in particular and of Malay cultural life in general" (Roff 1967, p. 144).

To achieve this, emphasis was placed on the development of the Malay language, literature and history. This effort was purely on the initiative of Dussek and his staff as the (official) British conception of vernacular education was utilitarian, intended only to equip rural Malay children with basic literacy and numeracy skills. Since lessons were entirely in Malay, a Translation Bureau was set up in 1924 to produce school texts. As an educator who had acquired "a passionate affection for the Malay people and a strong desire to be of service to them" Dussek (quoted in Roff 1967, p. 146) found it impossible to limit the intellectual content of the teacher training curriculum, claiming that he aimed "to educate teachers as well as train them, to raise the standard of vernacular schools gradually until secondary education also was possible ... in order to provide a suitable outlet for the brighter boys from rural schools" (ibid.). Hence, in addition to the school textbooks published under the Malay School Series, the Translation Bureau which was created and run by Dussek and Zainal Abidin Ahmad (Za'ba) also produced a Malay Home Library Series of classical Malay stories and translations of popular English literature for general reading among the increasingly literate peasant Malay population. As the translation and publication of Malay fiction was rather limited at the time, the Bureau's translations of English popular novels and plays may be perceived as an attempt to broaden the intellectual sphere of the Malay mind; although, as Warnk (2007) notes, both book series "presented a good picture of what European colonial educationalists wanted the Malays to read rather than of what Malays actually did read!” (p. 104) 


\section{Creating Malay Reading Material: Translations of Shakespeare in the Malay Home Library Series}

The colonial administration was not supportive of the initiatives of the Translation Bureau to provide reading material for the Malay public. It turned down a suggestion by Dussek and Za'ba in 1931 to expand the Bureau along the lines of the Balai Pustaka in Indonesia on the grounds that the British government could not appear to be aping the Dutch. Nevertheless, through the publications of the Malay Home Library Series Dussek was able "to bring healthy reading matter within the reach of every Malay villager" for 10 cents a copy, "a cost within the reach of every Malay villager's purse" (Abdullah Sanusi 1966, p. 61-62). Dussek further explained in his correspondence with Abdullah Sanusi that the selection of English texts for translation was a matter of individual preference. Dussek personally translated two Shakespeare plays, Macbeth and Julius Caesar, in collaboration with Muhammad Sa'id bin Haji Hussein primarily for staged performances. He must therefore have considered both plays to be suitable reading material "for the ordinary villager who as a rule was not very well educated"(Abdullah Sanusi 1966, p. 85). Macbeth was performed by the SITC students in 1932 (exact dates not stated) while Julius Caesar was performed on $25^{\text {th }}$ and $26^{\text {th }}$ August 1934. To aid the reader, synopses were included and the characters of each play were listed with accompanying notes to sum up each character. Julius Caesar for example is described as a brave warrior, generous to the needy, yet also given to acts of extravagance. ${ }^{1}$ King Duncan similarly is portrayed as a kind and loving ruler. ${ }^{2}$ Brutus meanwhile is characterised by intelligence, a quiet disposition, and great resolve. ${ }^{3}$ Macbeth is described as a brave warrior, initially generous and well respected by his subjects but later despised when he turns into a cruel and bad tempered tyrant under the influence of his manipulative wife. ${ }^{4}$ Lady Macbeth is unequivocally a villain, for she is greedy, ambitious and wicked besides being responsible for inciting Macbeth to evil. ${ }^{5}$ The didactic aim of the translations are thus, established from the outset.

\footnotetext{
${ }^{1}$ Gagah dan perkasa, murah hati, pemboros dan terbuka tangan-nya pada segala miskin.

${ }^{2}$ Baik dan penyayang kepada orang-orang besar dan ra'ayat.

${ }^{3}$ Berakal dan pendiam; segala perbuatannya bagai periok api ta'ada mendua fikirannya.

${ }^{4}$ [B] erani dan gagah perkasa dalam peperangan; perangai-nya lembut dan pengasehan serta di-hormati orang. Tetapi sa-telah menjadi raja menggantikan baginda, ia di-benchi oleh sekalian ra'ayat-ra'ayat kerana dzalim dan bengisnya, oleh sebab pujok dan kekerasan isteri-nya.

${ }^{5}$ Tama'; haluba akan kebesaran dan jahat budi pekerti-nya; pandai mengapi-ngapikan suami-nya.
} 


\title{
Feudalism in the Malay world
}

In his foreword to Macbeth Dussek states that he is faithful to the original text; however, simple colloquial Malay speech is used rather than poetry to make the play more accessible to the reader and the lines easier to remember for the actors. Macbeth and Julius Caesar arguably both translate easily for an audience from the Malay world who would be familiar with a feudalistic social order ${ }^{6}$ since Malay culture is traditionally feudalistic in nature. Kessler explains:

\begin{abstract}
Malay society and culture, as they conceive of themselves, rest centrally upon a political condition: upon people having and being subjects of a raja, a ruler. The polity, a kerajaan, is not only a ruler's domain but his subjects' sociocultural condition, that of having a raja. ... [T] he cultural presuppositions of a political order itself are the fundamental basis of Malay social existence. That social order is basically a political order and social existence is a political condition, one of being involved in the reciprocal relationship between ruler and ruled (1992, p. 136).
\end{abstract}

This feudal mindset is said to be a fundamental characteristic of Malay society and to a certain degree this remains true even today. Adherence to feudal values (through literature) is demonstrated in the legend of Hang Tuah, the most widely recognised icon of Malay heroism whose life's exploits are documented in a classic Malay text, the Hikayat Hang Tuah. Shaharuddin Maaruf analysed the character of Hang Tuah to show how he is motivated by blind personal loyalty to his master, the Sultan, arguing that the former devoted his life to loyal servitude that superseded ethical and moral considerations: right and wrong were discerned in terms of the convenience of the master. ${ }^{7}$ So steadfast was Hang Tuah to the principle of blind loyalty that he did not rebel nor seek justice even when his own life was at stake. When he fell victim to slander by his rivals resulting in a death sentence from the Sultan of Melaka, for example, Hang Tuah exclaims "Alhamdulillah [Praise God]! Tuah does not have two or

\footnotetext{
${ }^{6}$ Although Julius Caesar's Rome is a republic, one of the arguments put forward by Shakespeare's Brutus and Cassius for Caesar's murder is the fear that Caesar, buoyed by the people's adulation was turning into a tyrannical monarch.

${ }^{7}$ Shaharuddin b. Maaruf, Concept of a Hero in Malay Society (Singapore: Eastern Universities Press, 1984). In his introduction, Shaharuddin explains his concept of Malay feudalism, based on the writings of S.H Alatas who differentiates between Western feudalism and its Southeast Asian version. The differences however were mostly in details of form; of more relevance were the similarities, "particularly the psychological structures in the attitude of the [feudal] period" namely the "feudal psychology" whereby Shaharuddin focuses primarily on "the exploitative tendency on the part of the superiors [or ruling class] and the submissive mentality on the part of the subordinates" as portrayed in classical Malay texts.
} 
three masters and he has no intention of going against his master. Make haste in carrying out the command of the honourable master" (Shaharuddin 1984, p. 24).

As an ardent proponent of Malay education, Dussek would surely have been aware of the traditional feudal mindset of Malay society; besides which, he was assisted by his Malay co-translator, Muhammad Sa'id bin Haji Hussain, who would have provided valuable insight into the workings of Malay culture. Macbeth and Julius Caesar both portray regicide and its disastrous consequences. One could reasonably understand how this resonates with the Malay sensibility, perhaps even speculate that these two plays had been selected for translation and performance precisely for that reason. Dussek was reportedly firm in his conviction that "The Malay schools must be run for those Malays who will and must remain in the villages. They must have no connection and no point of contact with English; English and vernacular make very poor bed-fellows" (The Straits Times, 15 August 1935). Loh (1975) argues that Dussek's insistence on a monolinguistic policy was consistent with his personal vision for Malay language and culture, and also Malay vernacular schools; namely to create an environment which would nurture Malay culture and language, and eventually enhance the value of Malay education. During Dussek's tenure the SITC "became a hub of Malay literary activity, devoted to a critical evaluation of Malay society and the exhortation of the Malays to put more effort into "every department of life"' (Loh 1975, p. 88). The SITC-trained teachers also "brought into the villages to which they returned a new awareness of the social and economic problems confronting the Malay community" (ibid.). In short, Dussek's insistence on the cultivation of Malay language, literature and culture promoted "a new Malay consciousness" among his students which they later disseminated to the Malay community at large (ibid.). Thus, Dussek undertook to supply "healthy reading matter" for the Malay student and the Malay villager in the form of popular English tales rendered in Malay. English language may have been prohibited for the Malay peasants; English stories, ideas and ideals on the other hand were to be disseminated.

\section{Colonial Attitudes towards Malay Education}

Malay vernacular education was maintained (read financed) exclusively by the Government, hence was free of charge while the English schools (with the exception of 
the Malay college in Kuala Kangsar which the British set up to provide free English education for the sons of the Malay aristocracy) were maintained by American and French missionaries. ${ }^{8}$ Malay parents were generally wary of sending their children to be educated at these Christian establishments. The British administration was therefore committed to providing vernacular education to help the Malay community keep on equal footing with the Chinese. In a speech delivered at the Royal Colonial Institute in London in 1927 for example George Maxwell chides the British administration for its lackadaisical attitude towards funding for Malay education: "[I]t is rather disconcerting to find that the Chinese community, by a system of purely voluntary contribution, can provide education for its nationality in as high a proportion as that provided by the Government for the Malays."(Maxwell 1983, p. 402)

Despite - or perhaps, because of - his determination to keep the English language away from the Malays, Dussek devoted his career to the cause of Malay vernacular education and was instrumental in producing proper textbooks for the Malay schools. He reveals in correspondences with Abdullah Sanusi Ahmad that he was "the only European in the Education Department who specialized on the Malay side" and that he harboured ambitions of setting up a Malay University (Abdullah Sanusi 1966, p. 87). In Dussek's interviews with Roff conversely he explains the rationale for Malay education, its primary aim being "to educate the rural population in a suitable rural manner and equip them to continue to live a useful, happy rural life" (Roff 1967, p. 28). Given the class and socio-economic structure of the period, as well as the rather haphazard state of the British administration, this policy appears to be have been born as much out of pragmatism as imperialism: agriculture was after all the backbone of the Malayan economy. ${ }^{9}$ Dussek however planned to gradually raise the standard of the

\footnotetext{
${ }^{8}$ There were also Malay boys from the Malay schools who were given scholarships to urban English schools. One example was Mustapha Hussain who in his memoirs Malay Nationalism before UMNO (Kuala Lumpur: Utusan Publications, 2005) devotes a chapter to his recollection of English education at King Edward VII School, Taiping. He relates anecdotes of various unnamed teachers who taught him in his first few years who were less than sympathetic to the plight faced by Malay students who lagged behind their non-Malay counterparts in the command of English, and recommended that these students leave school or "be sent back where they belonged". Although he does not name these teachers one suspects that they were not British, but rather, English speaking Asiatics who were brought in to teach at English schools in Malaya. For Mustapha goes on to say that his time in the Junior Cambridge classes of Standards VI, VII and VIII went well since "I was beginning to get outstanding British teachers, not English-speaking citizens from other countries. These British educators were fair and just, in and out of class." (p. 55-61)

${ }^{9}$ It is also worth reminding ourselves that this was around the period of the Great (economic) Depression.
} 
Malay schools until they reached secondary level. His ultimate goal, as expressed to Abdullah Sanusi (ibid., p. 96-97) was for Malay to be the language of government; in the short term he aspired for local government at district level to be carried out in Malay to ensure that Malays should not be excluded. He faced an uphill task however, as the standard of teaching at the College was low, and the textbooks used were of a similarly dismal standard; more importantly, his vision for Malay education had no sympathy among the higher echelons of British administration. It is therefore not surprising to read the comment by writer and former teacher of the SITC, Harun Aminurrashid (quoted in Awang Had Salleh, 1979) that "[t]he books read by the children did not offer them any meaning.[I]nstead, [they] made the children feel small, humble and inferior, resulting in them having no ambition in life and adopting a feeling as if they were slaves" (p. 105-106). To overcome the dearth of suitable books, Dussek and his chief translator Za'ba worked overtime ${ }^{10}$ to supply sufficient quality reading material for the trainee teachers and also for the vernacular school boys. It is worth reiterating that the Translation Bureau was the brainchild of Dussek but he enjoyed no Government backing; in fact he had to slip in his expenses for the Bureau under the budget he commanded as Assistant Director of Education. Whilst the Dutch government's Balai Pustaka in Indonesia was staffed by 80 writers as well as a team of support staff, Dussek's Translation Bureau was manned by Za'ba and a handful of assistants: between 1924 and 1931 the number increased from 2 assistant translators to 12. Despite these setbacks Dussek, Za'ba and the Translation Bureau were able to publish a total of 64 titles for the Malay Home Library Series alone, as well as the Malay School Series. Such was their determination to provide quality reading material for the Malays.

\section{British Intervention in the Malay World}

British rule was officially introduced to the state of Perak in 1874 with the signing of the Pangkor Treaty. For much of the nineteenth century civil wars had been a recurrent feature in the Malay states, mainly resulting from quarrels over succession and territorial rights. Andaya \& Andaya (2001, p. 148) note that the ultimate victor in Malay

\footnotetext{
${ }^{10}$ Adnan Hj. Nawang, Memoir Za'ba.Tanjung Malim: Universiti Pendidikan Sultan Idris, 2005, p. 53. Za'ba writes that from 1925 till 1931 he worked nonstop at the Translation Bureau translating and editing textbooks, and this resulted in a nervous breakdown in 1931.
} 
wars was usually the one who could rally the strongest or most prestigious allies. The British government was initially opposed to any involvement in these Malay quarrels, with London adopting a policy of non-intervention. The involvement of non-Malays, in particular rival Chinese secret society groups who were themselves split by bitter quarrels often prolonged these conflicts and in areas of commercial importance such as the tin producing state of Perak, led to urgent calls for the British government in the Straits Settlements to "take steps in the Malay states to create a climate more conducive to investment and trade" (p. 149). The Perak sultanate adopted a system designed to prevent disputes by rotating rulership between the three different branches of the royal family. Even this system, however, did not succeed in reducing conflict: enmity existed between rival princes over the choice of rulers which, according to Andaya \& Andaya (2001), was further exacerbated by the ambitions of powerful Malay chiefs who aligned themselves to one or other of the feuding royals (p. 153). In November 1873 governor Andrew Clarke decided (on his own initiative) to settle the long running dispute between rival factions in the Perak royal household which was affecting the mining of tin. He requested the leading Perak Malays to meet him on Pangkor Island off the coast of Perak to settle the succession question. Meanwhile, the regent of Perak, Raja Abdullah, who had been bypassed for the throne, had also written to Governor Clarke inviting him to send a British Resident to Perak in return for which he (Abdullah) was to be recognised as the Sultan. This offer from Raja Abdullah resulted in the Pangkor Treaty of 1874 which recognized Abdullah as the sultan in return for his agreement to accept a British Resident (p. 158). The British Resident would later prove to be very influential, for his advice was mandatory on all questions of government except for those pertaining to Malay religion and custom. This was how the British created inroads to intervene in the running of the Malay states. As stated in Andaya \& Andaya (2001), "The significance of the Pangkor Treaty lies in the fact that it represented a turning point in the formal relationship between Britain and the Malay states" (p. 160). The British however were ill-prepared for the role they had assumed - as were the Malays. Misunderstandings over the scope of British authority caused much anger on the part of the Malays, particularly the commoner chiefs who suffered a loss of income and status due to the centralisation of revenue collection by the Resident. This measure was also viewed as a threat to the Malay state's independence since the state revenues would 
henceforth be placed under non-Malay authority. Collection of tolls and taxes was but one point of contention between the Malays and the British Resident which culminated in the murder of J.W.W. Birch, the first Resident of Perak in 1875 who was killed by a group of disgruntled Malay chiefs and nobles. ${ }^{11}$

From this inauspicious beginning however the British refined the Residential system. In 1876 Frank Swettenham (quoted in Andaya \& Andaya 2001, p. 174) declared the concept of 'indirect' rule to be the cornerstone of the system "to preserve the accepted customs and traditions of the country, to enlist the sympathies and interests of the people in our assistance, and to teach them the advantages of good government and enlightened policy." Through implementing 'indirect' rule the British sought to win the co-operation of the Malay ruling class and nobility by compensating them generously for the loss of income they had suffered. The British presence reduced the incidence of civil wars and enabled a measure of political stability: State Councils were created, comprised of the Resident, the Malay ruler, selected princes and chiefs, as well as a restricted number of representatives from the Chinese community. This was purported to be the sole legislative body; in truth, power was concentrated in the hands of the Resident since he nominated the members of the Council, proposed the legislation to be discussed and prepared the agenda. To ensure the smooth running of the system, however, the British were careful to maintain good relations with the ruling class, thereby establishing a gap between the ruling class and the rest of Malay society. Traditionally, the life of the sultan and the court had much in common with the peasants with whom they shared the same perception of the world and with whom they interacted; with British political intervention, however, the Malay elite began to adopt a Western lifestyle. This close association between the Malay ruling class and the colonial authorities disguised the fact that real power ultimately resided with the British (Andaya \& Andaya 2001, p.175-177). This was also true at district level, where a British district officer was placed in charge. He oversaw administration as well as revenue collection and the collection of land rents. Under his supervision were the Malay village heads or penghulu who drew a state salary for assisting in rent collection, administrating local

\footnotetext{
${ }^{11}$ For a Malay nationalist's perspective on the Birch murder see Mustapha Hussain, Malay Nationalism before UMNO. Kuala Lumpur: Utusan Publications, 2005, p. 6-10.
} 
justice and maintaining law and order. This system of administration installed by the British therefore resulted in formerly powerful local Malay chiefs being displaced, as only a few were appointed to become penghulu, or elected to the state Council.

Dussek's choices of Shakespeare plays should be scrutinised within this sociohistorical context, leading to the question: why, of all the plays in the Shakespeare canon, choose to translate two plays with - broadly speaking - similar concerns, namely, the unhappy consequence of rebellion ${ }^{12}$ A closer look at the translations, read against Malay political sensibility during the period when the plays were translated for performance would hopefully shed some light.

\section{Macbeth and Julius Caesar and Feudalism}

The translations of Macbeth and Julius Caesar were undertaken primarily for performance. They take the form of play scripts complete with stage directions and detailed descriptions of scenery and props for the stage managers. Macbeth is divided into two halves: Act One scenes I to III and following an intermission, Act Two scenes I to VI. Dussek summarises each scene, with a note at the end of each Act that music should be played between scenes to facilitate prop/set changes. Act One is shortened drastically, opening with a short scene of Macbeth, Banquo and their soldiers returning triumphantly from battle. Macbeth's dialogue is a short speech of thanks to Banquo and the soldiers for their courage, and a promise to speak well of them to King Duncan so that his majesty would reward them accordingly. Banquo replies that the victory is due mainly to Macbeth's skills and cunning at warfare, as well as his outstanding bravery. Macbeth then makes mention of the three witches and wonders at their prophecy, half of which has already come to pass. Banquo concurs that their prophecies are strange, but tells Macbeth not to think about them since they have just returned from battle and are exhausted. Such is the extent of the first scene. The audience does not see the witches as in the original; instead the play opens by focusing on Macbeth and his bravery. To retain the gist of the plot however, passing mention is made of the witches and their prophecy. Two possible explanations can be suggested for the editing of this scene: first, that the intention is to establish Macbeth's credentials as a brave warrior without

\footnotetext{
12 Roff agrees that Dussek's choice of texts "perhaps requires some explanation".William Roff, email message to author, September 22, 2008.
} 
the distracting spectacle of the supernatural which would accompany the appearance of the witches, thereby creating a greater impact when they eventually appear in Act Two. The other possible reason, bearing in mind Dussek's didactic intentions is that rural Malay society was by nature superstitious and had a great inclination for mysticism especially where their legendary warriors were concerned. Mustapha Hussain (2005, p. 20) recounts that kampung (village) life was replete with "an assortment of beliefs, taboos and superstitions" and a belief in the powers of bomohs or Malay shamans. One of the first instances of Malay rebellion against the British was the previously mentioned assassination of the first British Resident, J.W.W. Birch in 1875 which took place in Matang, a village not far from Tanjung Malim where the SITC was situated. According to local legend, Datuk Sagor, one of the Malay chiefs implicated in the Birch murder was sentenced to death by hanging. The sentence was executed accordingly, but Datuk Sagor would not die until a nail soaked in lard was nailed to the top of his head before hanging him again. Legend also states that his body was later cut in two and buried on either side of the Perak river (the river in which Birch was waylaid and stabbed to death) because it was believed that the body would reunite if the two parts were buried on one bank (Mustapha Hussain 2005, p. 7-8). Such stories were part of the rural Malays' belief system; as such there existed a link between mysticism and nationalist rebellion in local lore to which Dussek may not have wished attention drawn - especially since the witches initially predict good tidings for Macbeth. Dussek may also have wished to avoid confusing the Malay audience as to the moral status of the witches. Since the consulting of shamans was part of Malay traditional culture, the witches might possibly have been viewed as forces of good. This suspicion is further strengthened when one considers the stage directions much later in Act Two Scene IV of Macbeth (1934) where the protagonist confronts the witches in their cave: "The scene with the witches is played in shadows. Draw the curtains - all is dark. Flashes of light are shown, as if lightning with the use of torch lights. Loud, frightening noises to accompany the scene" (p. 23). Here the witches are shown as evil creatures; by this stage of the play at any rate Macbeth has already become associated with evil and murder. He has made the transition from heroic figure to evil villain and is worthy only of condemnation from the audience. ${ }^{13}$

${ }^{13}$ Of course, another reason for leaving out entirely the early scenes with the witches may be that 
In Dussek's translation there is no equivocation, no room for contemplation and introspection. Macbeth reasons that it would be courting disaster to kill Duncan, besides being immoral and despicable on so many levels; in the next breath however he is imagining the dagger, dripping with blood which vision so scares him that he goes mad. Add to his disturbed psyche the unceasing urgings of Lady Macbeth. Such intense pressure would be enough to push anyone over the edge and this is precisely the spectacle presented to the Malay audience. ${ }^{14}$ The subtext here is clear: it is evil and wrong to kill the ruler especially one as benign, just and beloved by his subjects as Duncan. Only a madman would commit such an abominable act and this is exactly how Macbeth is portrayed. Prior to this he has been shown as a valiant warrior fighting for his king and country and as such, cannot have been in his right mind to even contemplate murdering his king. The idea of regicide would probably have been beyond the contemplation of traditional Malay society. To illustrate this point, consider again Shaharuddin Maaruf's analysis of traditional Malay hero Hang Tuah based upon the classic Malay text, Hikayat Hang Tuah, which details Hang Tuah's unwavering loyalty to the Sultan of Melaka:

\begin{abstract}
[Hang Tuah] was mainly motivated by blind personal loyalty to his masters. Such loyalty superseded ethical and moral considerations. Right and wrong were defined in terms of the convenience of the master. Erich Fromm's description of the conscience in authoritarian ethics touches on this aspect of feudal psychology: 'Good conscience is consciousness of pleasing (the external and internal authorities); guilty conscience is the consciousness of displeasing it. The good (authoritarian) conscience produces a feeling of well being and security, for it implies approval by and closeness to the authority; the guilty conscience produces fear and insecurity because acting against the will of the authority implies danger of being punished and what is worse of being deserted by the authority (1984, p. 23).
\end{abstract}

Even when unjustly sentenced to death on two separate occasions by the Sultan, Hang Tuah remained loyal — as mentioned above — and displayed total resignation and submission: "Tuah has no intention whatsoever to go against the master and I do

immediately after scene 1 Macbeth is shown at home with Lady Macbeth and he describes to his wife at length his mysterious encounter with the witches, and the predictions they made for him, hence the opening scene was omitted simply to save time!

${ }^{14}$ Although no reviews could be located for the College performance one could reasonably assume that the audience would have comprised at the very least, Malay boys who were students of the College at the time. 
not serve another .... Total servitude is what I seek. It is best that you ... carry out the sentence, for my life is my master's to do as he pleases!" (p. 24). Shaharuddin observes that Hang Tuah's blind loyalty to the ruler conforms to Fromm's notion of the authoritarian ethics where "The prime offence in the authoritarian situation is rebellion against the authority's rule" (ibid.). Malay society pledges subservience to the ruler; to rebel against his authority is an offence punishable by death. Therefore, to kill the ruler was treasonous beyond redemption and anyone who could even contemplate such a heinous deed had to be insane. Macbeth's treason could only spell doom for him eventually; as such the Malay audience would naturally have anticipated disaster to befall the unfortunate protagonist-turned-antagonist. They would have approved of Macbeth's bloody end as well deserved.

In Julius Caesar (1935) however a slightly different scenario is presented. As a prelude, Dussek includes a brief summary of Roman history up until the death of Julius Caesar. In this summary, he notes that Rome was a Republic, no longer ruled by the monarchy. He describes Caesar as being a very determined, ambitious young man from the aristocracy. ${ }^{15}$ Caesar is also described as a good orator and skilled diplomat. He is generous, charitable and enjoyed sport. This resulted in him being well loved by the people of Rome (p. ii). ${ }^{16}$ Caesar's military exploits are also detailed in Dussek's summary. His triumphant return to the city and his rapturous welcome is described. He is so revered that his status is akin to that of a demi-god, and he is the first man to be proclaimed ruler of Rome for as long as he lives (p. iv). ${ }^{17}$ His immense popularity and power is the envy of his enemies, and this incites them to treason which culminates in his murder on 15 March 44 B.C.

Some creative editing is performed on the character of Brutus; instead of portraying him as a thinker manipulated into committing treason by the cunning Cassius, he is instead presented as someone who poses as a patriot and commits murder

\footnotetext{
15 Julius Caesar ini ia-lah keturunan daripada orang-orang yang berpangkat dalam negeri Rome itu. Apabila ia telah besar, terbitlah chita-chita yang amat keras di-dalam hati-nya hendak mendapat jawatan yang tinggi-tinggi dalam negeri itu.

${ }^{16}$ Maka orang-orang semua memuji Caesar, kerana ia pandai bersharah dan bijak berbichara dalam hal siasat negeri. Lagi pun ia pemurah dan suka champor dalam segala permainan, tiada takut berbelanja; yang demikian menjadikan tertambat kaseh umiputera negeri Rome kapada-nya.

${ }_{17}$ Dan lagi ia di-angkat menjadi pemerentah yang pertama bagi negeri Rome salama ada hayat-nya. Pendek-nya berbagai-bagai-lah kebesaran yang di-beri kapada-nya hingga di-angkatkan martabat-nya itu sama seperti dewa-dewa ...
} 
for the sake of his motherland. Brutus' actions can thus be loosely aligned to those of another character from the Malay world, Hang Jebat. Like Hang Tuah, Hang Jebat was a warrior in the Sultan's court. Unlike Hang Tuah however, Jebat was not the obedient feudal servant of his master the Sultan. Jebat rebelled against the Sultan and went on a killing spree (ran amuck), stabbing courtiers in the Sultan's palace to seek revenge against what he perceived as the unfair death sentence meted out to his best friend Hang Tuah who had been maligned by jealous rivals. Jebat thus took it upon himself to be judge and executioner. The same could be said for the character of Brutus in Dussek's translation. In the text, Cassius, arguing for the removal of Caesar, alludes to the injustice of Caesar reaping the fruits of the Romans' labour. This point would have resonated with the Malay audience who were familiar with feudal Malay practices recorded in classic Malay texts such as the Misa Melayu and Sejarah Melayu. Shaharuddin quotes Abdullah Munshi's Kesah Pelayaran Abdullah where war between the Malay chiefs resulted in hardship to the people, and concludes

We can safely assume that the subjects were burdened with the war cost. They were also compelled to fight in these wars. There was an institution of forced labour known as kerah, which gives the rajas the right to the labour of his subjects without remuneration. Whatever work the raja needed doing, the subjects could be ordered to do it... (Shaharuddin 1984, p. 30).

Such "unjust leadership in Malay feudal society" (p. 31) as Shaharuddin puts it was common knowledge at the time, and is well documented in classic Malay texts. Shaharuddin further asserts:

The values of the Malay feudal court were in conflict with those of the Malay masses and the peasantry which depended on labour. The Malay masses emphasized the qualities of neighbourliness, co-operation, conformity and perseverance. This conflict in the values of the ruling group and the subjugated people is a central feature in Malay feudalism ... (p. 33).

The audience at the SITC students' performance of Julius Caesar would probably have consisted of local Malays who lived in the state of Perak which had 
gradually been placed under British rule over the previous fifty years. ${ }^{18}$ Some audience members may even have remembered life as feudal subjects of the Perak Sultan. They would possibly have disagreed with Brutus and Cassius' justification for murdering Caesar (never mind that Rome was a republic by that time) since he was the ruler of Rome, and murdering him was derhaka (treason), a crime punishable by death.

The question of Caesar's propensity for tyranny is a central issue in Shakespeare's play. The translated version of Julius Caesar however only alludes to this without explication or exploration. The performance is divided into two parts, the first depicting Brutus' inclusion in Cassius' plot to murder Caesar and climaxes with the stabbing of Caesar, closely followed by the arrival of Antony to bury Caesar. The second part dramatises the aftermath of the murder, Antony's speech and the ensuing unrest it causes, culminating in Brutus' suicide. Caesar only appears in one scene the scene at the Capitol where he is eventually stabbed to death. The audience's impression of Caesar is therefore shaped entirely by this brief appearance, later supplemented by Antony's speech. In the published translation, the reader has further guidance: a page is included immediately after the list of dramatis personae on which are details of the main characters' defining qualities. The translators thus shape the audience's/reader's impression of the characters directly through these character sketches, and indirectly through the omission of dialogue and entire scenes. The published translation extols Caesar's virtues, depicting him as a brave warrior, generous and extravagant yet charitable to the poor (p. vii). ${ }^{19}$ What impression is created of Caesar onstage? In Act 1 scene 2 his first appearance marks his arrogance, for he smilingly mocks the soothsayer who warned him to beware the $15^{\text {th }}$ of March. He is then approached by Artemidorus with a short note (schedule). Caesar initially questions whether the note contains anything of importance ${ }^{20}$ then wonders aloud as to whether Artemidorus is mad, but nevertheless, accepts his note. Caesar exits, leaving the conspirators to worry and wonder if their plot has been discovered. In this short appearance, Caesar is thus shown to be arrogant and dismissive but more importantly he

\footnotetext{
${ }^{18}$ Unfortunately no published reviews of the two performances have been turned up. SITC was used as a military base during the Japanese occupation (1941-1945) hence any English/British publications found were very likely to have been destroyed by the Japanese soldiers.

${ }^{19}$ Gagah dan perkasa, murah hati, pemboros dan terbuka tangan-nya pada segala miskin

${ }^{20}$ Oh! Apa benar-lah isi-nya surat-mu itu yang berfaedah pada-ku itu?
} 
is isolated; whereas the conspirators work together to ensure the success of the plot. Caesar enters again and informs Brutus that he will take his leave since there is no other business requiring his attention. Metellus Cimber then kneels before Caesar to plead his case, and praises Caesar, "Oh most honoured Caesar, most generous Caesar" but Caesar cuts him short, insisting that he is as immovable as Mount Olympus, hence will not be moved by flattery and remain firm by his decision to banish Metellus' brother Publius Cimber. Again, Dussek's translation truncates the exchanges between Caesar, Metellus and Brutus who attempt to plead on Plubius' behalf. The language here is reminiscent of the special Malay form of address used when approaching the ruler. Brutus says, "Caesar hamba pohonkan dengan sa-tinggi-tinggi daulat tuan di-benarkan apa-lah kira-nya kebebasan adek Metellus Cimber itu balek ka Rome ini”. The personal pronoun "hamba" which literally means "slave", is only uttered when a commoner addresses royalty. Similarly Brutus speaks of Caesar's "daulat" which is a Malay term for the ruler's royal power. According to Malay tradition the ruler (Sultan or Raja) was specially appointed by God (Shaharuddin 1984 p. 20), hence this was the source of his "daulat". Brutus' plea translated into English would be "Caesar I appeal to your divine royal power that Metellus Cimber's brother may have freedom of repeal." Cassius likewise prefaces his plea by paying respects to Caesar using the Malay expression of servitude when addressing royalty: “Ampun tuanku, hamba sembah-lah tapak kaki tuan ..." ("Forgive me your highness, I worship at the sole of your foot"). Dussek's inclusion of Malay courtly language enacts a direct association between Caesar and the Malay ruler. This has a powerful effect in shaping their response to the murder of Caesar. In the Malay historical text Sejarah Melayu (Malay Annals) which traces the origins of the Malay rulers there is an important episode between Demang Lebar Daun, a Malay chief and his ruler, Seri Teri Buana where a "social contract" is outlined between the two. This episode in the Malay Annals is of prime importance to Malays because it defines the relationship between the ruler and his subjects: the subjects must remain loyal to their ruler and never betray him (durhaka) even though the ruler may be cruel and unjust of character (Tun Seri Lanang 1997, p. 23-24). As such, the sight of Brutus, Cassius and their accomplices plunging their keris into Caesar's chest would be a particularly shocking spectacle to an audience in the Malay world. 
To take the analysis a step further in an attempt to answer the question as to what Dussek's "agenda" may have been in translating these two Shakespeare plays, it may help to consider the collective effect of such staged performances on the Malay audience. A striking similarity between both plays is that the perpetrator in both instances was a character portrayed as being close to the ruler, someone trusted and beloved. Macbeth was a General of the King's army but he was also related to King Duncan; similarly, Brutus is described in the cast list as Orang besar (aristocrat) and sahabat Caesar (Caesar's friend). Of the other conspirators, Cassius is Brutus' brotherin-law while Casca, Trebonius and Metellius Cimber are called Undang which is the Malay equivalent for members of the Senate. The traitors were not mere villagers or ordinary subjects. They were members of high standing and leaders in their respective communities; yet these were the characters who murdered the monarch. Given the Malays' absolute loyalty to their Sultan, such actions ought to have been viewed as utterly reprehensible - especially since both rulers are portrayed as good leaders, kind and generous to their subjects. In the context of both plays, treachery and murder is thus unwarranted and unjustified. As mentioned above, Malay royal houses had in the past frequently quarrelled amongst themselves leading to civil wars and unrest. The Resident system in fact was introduced to Malaya as a result of one such quarrel in the kingdom of Perak. The British practice of "indirect rule" resulted in the centralising of power and revenues - in the hands of British Residents who were the "advisors" to the Sultans. This meant that many Malay commoner chiefs and lesser princes were left out of the pecking order, having been relieved of their traditional duties of collecting taxes and other revenue at district level for the Sultan, which would have caused these chiefs loss of income and status. Such dissatisfied individuals had been known to rebel against the British. Birch, the first British Resident to the state of Perak famously had been murdered by a group of disgruntled Malay chiefs in 1875. Other notable cases of rebellion had taken place in various Malay states - Tok Janggut in Kelantan (1915) which came under British rule following a treaty with Siam, and Mat Kilau (1880-1890) in Pahang were names of rebels well known to the British. The British cultivated the Malay aristocracy and maintained good relations with the Sultans, allowing them to appear as the rulers while in reality, the actual running of the state and important executive decisions came under the purview of the British Residents - with the 
blessing of the Sultan, of course. By capitalising on the Malays' traditional loyalty to their Sultans on the one hand, and appeasing the Sultans on the other with a large allowance (but little real power), the British ensured their "indirect" control over the Malay states.

\section{Conclusion: Dussek, Malay culture and nationalism}

How prevalent was Malay political awareness in the 1930s? Rustam Sani maintains that the Malays of that era still upheld the traditional political system with the Sultan as the absolute monarch. The Malays did not yet harbour anti-colonial sentiments at this time because the British policy of indirect rule maintained the facade of the state being ruled by the Sultan. Furthermore, economic development had resulted in the emergence of a multiracial society, brought about by the influx of Chinese and Indians, initially temporary economic migrants who later decided to make Malaya their home. Of these two groups the Chinese were more conspicuous in urban areas and were seen by the Malays to be more advanced economically whereas the majority of the rural Malays were still mainly involved in self-sustaining agriculture. At the same time, a new administrative elite had been created by the British which consisted mainly of English educated Malays from the aristocratic class, as well as Indians brought over from India to act as lower level adminstrative staff. The fear of being sidelined in their own land prompted the rural Malays to seek political mobilisation outside of the traditional Malay ruling elite. These early stirrings of political awareness however should not be viewed as an expression of nationalism according to Rustam (2004) since they did not fight for a nation state so much as for the concept of a unified Malay "race" (p. 1-27). Malay students at the SITC had access to the wave of pan-Malay nationalism sweeping across the archipelago from Indonesia mainly through its literature; Malay society by contrast was slow to profess anti-colonialism partly because of the close ties that existed between the British administration and traditional Malay rulers. As far as the Malays were concerned, the Sultan was the ruler of the state and he received advice from the British Resident. To rebel against the British would perhaps be flirting with treason (derhaka). An important observation by Rustam is his contention that Malay society during this era was separated into two clear groups namely the ruling class and their rural subjects $(2004$, p. 2). In the late 1930 s however a new group of Malays 
emerged to lead nationalist movements and these were mainly teachers, some of whom were graduates of the SITC. Farish (2002) considers this unexpected turn of events an ironic failure on the part of the Colonial education policy:

While the MCKK produced a number of compliant Malay clerks and peons (of royal birth, no less) to man the middle and lower echelons of the Colonial bureaucracy, its sister-institution the SITC produced a generation of educated and conscientious Malay youths who came to see their plight from a different perspective. From this group of newly-conscious Malay youths a handful of radical young Malay journalists, writers, teachers and activists would emerge, who would later become the founding fathers of the Malay radical nationalist movement (p. 78-79)

Farish suggests that these activists were

an unstable phenomenon: they were the indigenous intelligentsia who were clearly not impressed by the ameliorating claims of the Colonial-Capitalist discourse, but they were not about to return to their villages with their heads bowed in disappointment and disillusionment either (p. 80).

These young men

occupied the intermediary space between the two points that had been allotted to them: the urban Colonial administration (entry to which required a familiarity with Eurocentric discourses of modernity, Colonial-Capitalism as well as the English language), and the rural traditional administration (entry to which required precisely the opposite: the return to Colonial constructions of nativism, traditionalism and religious conservatism) (Farish 2002, p. 80-81).

Despite being, to all intents and purposes, an implementer of the colonial education policy of "division and containment" (ibid. p. 78), Dussek claims that he was determined to expand the horizons of his students' education so that they in turn could provide better education for the rural Malays. He acquired better Malay textbooks and general reading matter, either from Indonesia or by translating texts at the SITC Translation Bureau. He also encouraged a more literary education based on Malay language and culture. To enhance the status of Malay language and culture, he produced two Malay Shakespeare plays, Macbeth and Julius Caesar. These plays depict civil unrest as the inevitable consequence of treason which could only occur as a result of insanity or political jealousy. As the analysis above has suggested, both translations arguably propagate the importance of being loyal subjects, in itself a notion well within the traditional world view of the Malay psyche. 
Dussek's dedication to the cause of Malay education was nevertheless well appreciated by the Malays long after he had resigned from the SITC. Roff (1967) quotes the (Malay) secretary of the Former Pupils Association in 1961, who noted: "Throughout the time he held his job, Mr. Dussek showed the qualities not of a colonialist but of an educator whose real responsibility was to our own people" (p. 146). This view of Dussek as a member of the colonial administration who cared more for the betterment of the Malays than his role as colonialist is also acknowledged by Kamaruddin M. Said (2001), who observes that Dussek encouraged and nurtured the growth of Malay literature during the colonial period. He [unwittingly?] stimulated the Malays' appetite for liberation by inviting Indonesian nationalists like Tan Malaka, Sutan Djenain and Muchtar Lutfi to the College who fired the imagination of the Malay boys through their talks on nationalism in other parts of the Malay world. Dussek's commitment to Malay education for his College boys was however considered too radical and as such, the Colonial Office in London decided to retire him prematurely when he went home for a holiday. In the light of such Malay acknowledgement of Dussek's contribution to Malay education born of his concern for the Malays, the two SITC translations and performances of Shakespeare should perhaps be read more as one individual's attempt to expand the intellectual horizons of the Malays rather than the insidious workings of an imperialist agenda. The subtext of both performances is clear: unite under the Sultan, or risk anarchy. As a populace divided by social class, the Malays needed the occasional reminder to unite behind their traditional ruler especially in the face of serious challenges mounted to their social and economic standing by the immigrant Chinese community who were increasingly making their economic presence felt in the Malay world. ${ }^{21}$ For this reason, Dussek's translations of Shakespeare, ironically, worked to promote a Malay agenda rather than a colonialist one. Perhaps, this was his goal all along.

\section{Bibliography}

\footnotetext{
${ }^{21}$ Amazingly, such warnings of "external" threats to Malay sovereignity have been frequently recycled throughout the years by certain quarters in the attempt to unite the Malays for self-serving political expediency.
} 
ABDUlLAH Sanusi Ahmad. Peranan Pejabat Karang Mengarang dalam bidangbidang pelajaran sekolah-sekolah Melayu dan kesusasteraan di kalangan orang ramai. Kuala Lumpur: Dewan Bahasa dan Pustaka, 1966.

ADNAN Hj. Nawang. Memoir Za'ba. Tanjung Malim: Universiti Pendidikan Sultan Idris, 2005.

ANDAYA, Barbara Watson; ANDAYA, Leonard Y. A history of Malaya $2^{\text {nd }}$ Edition. Basingstoke: Palgrave, 2001.

AWANG Had Salleh. Malay secular education and teacher training in British Malaya. Kuala Lumpur: DBP, 1979.

DUSSEK, O.T; MUHAMMAD Sa'id bin Haji Hassan (trans). Macbeth. Tanjong Malim: Pejabat Karang Mengarang, Sultan Idris Training College, 1934. Julius Caesar. Tanjong Malim: Pejabat Karang Mengarang, Sultan Idris Training College, 1935.

FARISH A. Noor. The other Malaysia. Kuala Lumpur: Silverfish Books, 2002.

KAHN, Joel S.; LOH, Francis Kok Wah (Eds). Fragmented vision: culture and politics in contemporary Malaysia. Sydney: Allen and Unwin, 1992.

KAMARUDDIN M. Said. Orientalisme, pascakolonialisme dan kepengarangan Melayu. In: MOHD Hamin Mastor et al. (Eds). Nasi ayam laut sepinggan. Kuala Lumpur: Utusan Publications, 2002, p. 133-193.

KESSLER, Clive S. Archaism and modernity: contemporary Malay political culture. In: KAHN, Joel S.; LOH, Francis Kok Wah (Eds). Fragmented vision: culture and politics in contemporary Malaysia. Sydney: Allen and Unwin, 1992.

KRATOSKA, Paul (Ed). Honourable intentions. Singapore: Oxford University Press, 1983.

LOH Fook Seng, Philip. Seeds of separatism: educational policy in Malaya 18741940, Kuala Lumpur: Oxford University Press, 1975.

MAXWELL, George. Some problems of education and public health in Malaya. In KRATOSKA, Paul (Ed). Honourable intentions. Singapore: Oxford University Press, 1983, p. 401-422.

MOHD Hamin Mastor et al. (Eds). Nasi ayam laut sepinggan. Kuala Lumpur: Utusan Publications, 2002. 
MUSTAPHA Hussain. Malay nationalism before UMNO. Kuala Lumpur: Utusan Publications, 2005.

ROFF, William R. The Origins of Malay nationalism. New Haven and London: Yale University Press, 1967.

RUSTAM A. Sani. Ke mana nasionalisma Melayu? Kuala Lumpur: R Publishing Services, 2004.

SHAHARUDDIN b. Maaruf. Concept of a hero in Malay society. Singapore: Eastern Universities Press, 1984.

TUN SERI LANANG. Sulalat-al-Salatin (Sejarah Melayu). Kuala Lumpur: Dewan Bahasa dan Pustaka, 1997.

WARNK, Holger. The Role of Translations in the Development of Modern Malay Literature, 1850-1950. Journal of the Malaysian Branch of the Royal Asiatic Society vol.80 Part 1 no. 292 (June 2007), p.91-113. 